\title{
Detrás de la economía hay personas
}

\author{
Laura Arias Pacheco ${ }^{1}$
}

En todas las sociedades y en todas las unidades familiares, las personas deben enfrentarse diariamente a la toma de decisiones sobre cómo obtener un rendimiento óptimo a partir de cada una de sus acciones. Esas decisiones no sólo involucran ganancias en el ámbito financiero, sino también, dadas la diversas dimensiones del ser humano, en aspectos como la satisfacción personal y la de sus allegados.

En el ámbito individual cada persona puede decidir qué acciones llevar a cabo para maximizar su bienestar: dónde vivir, qué estudiar o cómo alimentarse, etc. Pero cada una de esas decisiones también dependen en mayor o menor medida del entorno económico que le rodea: los precios de las mercancías, la disponibilidad de unos bienes o servicios con respecto a otros, el tipo de cambio, las posibilidades en el mercado laboral, etc. Estos y el resto de los

1. Economista costarricense. Actualmente esta dedicada a los estudios del género. E-mail: laurahotmail.com 
elementos de la economía donde las personas están inmersas afectan de muchas maneras sus vidas cotidianas, y es muy poco lo que las personas pueden hacer para adaptar la economía a sus necesidades, pues las decisiones económicas de un país queda en manos o del ministro de hacienda o de un grupo reducido de personas como indica Joseph Sitiglitz. Aunado a esto, lo habitual es que las personas no posean conocimientos básicos sobre el funcionamiento de la economía de su país y eso hace que le sea más difícil elegir y decidir cuál política económica se encuentra más de acuerdo con sus necesidades e intereses, o comprender cómo determinada medida económica les afectará en el futuro, pues no poseen suficientes elementos de juicio acerca de dicha materia.

De ahí la importancia de incorporar dentro de la currícula educativa (secundaria y/o universitaria) elementos básicos de economía, en donde se consideren tanto sus aspectos técnicos como éticos para que los ciudadanos (as) puedan tomar decisiones adecuada a sus necesidades, para esto es necesario primero aclarar algunos conceptos.

Es importante que los lectores (as) sepan que la palabra economía viene del griego y que en sus orígenes significaba la administración o el diestro gobierno de la casa. La mayor parte de los diccionarios especializados olvidan este origen y definen la economía como la disciplina que estudia las formas en que la sociedad se organiza para manejar el problema básico de la escasez. Se parte de la tesis de que todas las sociedades tienen más necesidades que recursos y que dichos recursos son limitados. Por ello, los estudiosos de la economía deben idear sistemas para asignar recursos escasos hacia fines o necesidades alternativas.

Cabe resaltar también que la economía es una disciplina compleja y paradójica al ser un híbrido entre Ciencias Sociales y Ciencias Exactas. Pues no sólo se ocupa de 
analizar el comportamiento económico de las personas en lo individual-colectivo, sino que construye modelos matemáticos y estadísticos para intentar explicar estos comportamientos. Y dado que los modelos constituyen sobresimplificaciones de la realidad, inevitablemente dejan de lado diversos aspectos y motivaciones propias de los seres humanos que también influyen en su accionar económico.

Es importante e ilustrativo referirse aquí al planteamiento que hace el economista, premio Novel de economía en 1998 y de origen hindú, Amartya Sen en su libro Sobre Ética y Economía. En este libro Sen critica los análisis económicos modernos porque estos han producido un grave distanciamiento entre ética y economía, lo que hace que la economía contemporánea se haya empobrecido, convirtiéndose en una ciencia que se ocupa de la mera asignación "eficiente" de los recursos. Sen nos recuerda que esto no fue siempre así. En el pasado la economía se consideró una rama de la ética, y hasta hace poco en Cambridge se enseñaba como parte de la "Diplomatura en Ciencias Morales". De hecho, Adam Smith, el llamado padre de la economía moderna, era profesor de Filosofía Moral en la Universidad de Glasgow.

La economía tiene dos orígenes: la ética, que con la pregunta "¿Cómo hay que vivir?" se ocupa y señala los logros o los fines por alcanzar, y la técnica, que se ocupa más de los medios y-de cómo alcanzar ciertos fines. En el enfoque técnico, las motivaciones de las personas se explican en términos simplistas y se vuelven excesivamente reduccionistas; ya que comprenden la ausencia de bondad, la misma que caracteriza a la economía moderna. Es decir, no se consideran motivaciones morales más complejas al analizar el comportamiento humano real.

Dice Sen que a partir del supuesto clásico de la economía de que el ser humano es egoísta, ha sido sumamente 
dañino para la calidad del análisis económico, porque los supuestos puede ser erróneos. Así, Sen no comparte la tesis de Adam Smith de que el "hombre económico" se comporta en forma racional si busca maximizar su propio interés o su propia utilidad y que la maximización del interés o la utilidad individual es una fuerza para maximizar la riqueza total de una nación.

Para Sen esto implica que el comportamiento racional es equiparado con la maximización del propio interés. El se pregunta por qué debe ser únicamente racional perseguir el propio interés, excluyendo todo lo demás. Porque de acuerdo con este supuesto, cualquier cosa que se aparte de la maximización del propio interés es "irracional".

Sen considera que este supuesto es muy restrictivo, reduccionista y que ha impedido el análisis de relaciones significativas. No se cuenta con ninguna evidencia para afirmar que la maximización del propio interés es la mejor aproximación al comportamiento humano real, ni para decir que lleva necesariamente a condiciones económicas óptimas.

No obstante, Sen aclara que no se trata de eliminar este supuesto, pues de hecho ha aportado una mayor comprensión a muchos temas, y es innegable que la motivación individual "egoísta" es un motor poderoso para alcanzar ciertos fines. Lo que critica es la tendencia del análisis económico a considerar la motivación egoísta como la única razón que explica el comportamiento de los agentes económicos.

Sen hace hincapié en el hecho de que las consideraciones éticas también afectan el comportamiento humano, pues si se les presta atención, la economía podrá volverse más productiva. Para sustentar su posición, Sen destaca algunas desviaciones o anomalías respecto al paradigma del comportamiento egoísta. En primer lugar, menciona como ejemplo la economía japonesa. Japón ha logrado alcanzar 
un enorme éxito industrial, y prosperidad económica tanto en el ámbito individual y colectivo, desviándose sistemáticamente de la tesis del comportamiento egoísta hacia otras motivaciones como la lealtad, el deber y la buena voluntad. El carácter japonés, y su sistema de valores dominantes distan mucho de encajar dentro de un comportamiento egoísta.

Otro ejemplo de desviación del comportamiento egoísta en el comportamiento real de las personas, son las acciones basadas en la lealtad al grupo o la familia, que suponen a veces un sacrificio de los intereses puramente personales. La imagen por excelencia con quién se puede asociar este tipo de acciones es la de las mujeres, quienes en general piensan primero en las necesidades de los demás antes de siquiera entender cuáles son las propias.

En consecuencia, esta separación de los aspectos éticos ha debilitado el alcance e importancia de la economía, y la ha reducido a un área del conocimiento reservada para unos pocos especialistas que, a pesar de sus buenas intenciones, siempre se ven superados por el poder de los políticos para imponer sus criterios. Así, si una medida necesaria para sanear la salud económica del país no es "políticamente viable" pues afectaría eventualmente el caudal d e votos, terminará archivada en cualquier rincón.

Lo anterior intenta justificar la importancia de que las personas tengan conocimientos básicos de economía, tanto de sus aspectos técnicos como éticos, pues no sólo contarían con más criterios para influir sobre su propia situación económica, sino para entender el alcance de determinadas medidas, apoyándolas o rechazándolas.

Esto permitiría una mayor participación de la gente en la conducción de la política económica de un país, y por ende un mayor ejercicio de su ciudadanía. Esto se hace urgente sobre todo en América Latina y el resto de países 
en vías de desarrollo: la enorme falta de información y la desinformación en materia económica han permitido que se manipule y se empobrezca a la gran mayoría de sus poblaciones.

Dado que como se mencionó al inicio de este artículo, la vida cotidiana de las personas está fuertemente influenciada por el contexto económico que les rodea, es fundamental que tengan acceso a más y mejor información económica. Saber por ejemplo las implicaciones de determinada política económica sobre sus ahorros en moneda local, sobre sus deudas en moneda extranjera, sobre la solvencia de la instituciones bancarias en que guardan su dinero, sobre sus posibilidades de accesar más y mejores empleos.

El hecho es que detrás de la economía y sus supuestos, hay personas con necesidades, aspiraciones y motivaciones diferentes. Cada una de esas personas tendrían más elementos de juicio para tomar decisiones si contaran con conocimientos básicos acerca del entorno económico y ético que les rodea.

Lo anterior ayudaría a identificar más claramente la raíz del problema como la corrupción, los salarios bajos, la insuficiencia e ineficiencia de los servicios públicos, el déficit fiscal y la inflación, entre otros. De esos problemas se habla todos los días, pero el grueso de la población no sabe de qué se trata, de dónde surgen, y por lo tanto qué medidas son las más adecuadas para atacarlos. Así son presa fácil de la politiquería, las promesas y las soluciones cortoplacistas.

El conocimiento es poder, y el que las personas tengan un mayor acceso al mismo le permitirá tener criterios que sean menos manipulables por intereses políticos-electorales, y que puedan dar un paso adelante hacia la superación individual y colectiva de todos los actores sociales. 


\section{BIBLIOGRAFÍA}

SEN, Amartya. Sobre Ética y Economía. Madrid: Alianza Editorial, 1999.

PIERCE W, David. The MIT Dictionary of Modern Economics. Cambridge, Massachussetts: The MIT Press. 4a. De. 1994. 